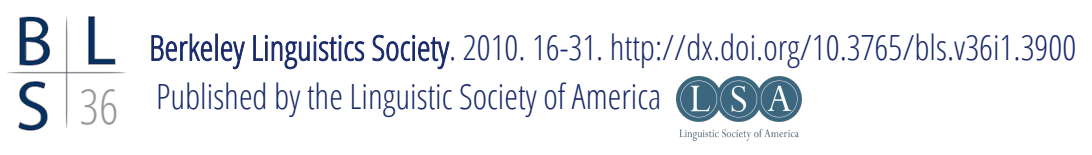

\title{
Language Isolates and Their History, or, What's Weird, Anyway?
}

\author{
LYLE CAMPBELL \\ University of Hawai 'i at Mānoa
}

\section{$1 \quad$ Introduction}

How many language isolates are there in the world? (How many language families are there?) Most linguistics do not know, and opinions vary greatly. The answers to these questions are complicated because they depend on different views about fundamental issues in historical linguistics. The goal of this paper is to attempt to answer the questions: How many language isolates are there? How can we advance knowledge of the history of language isolates? What methodological lessons does the study of specific isolates offer to understand better the history of language isolates in general and that of other specific isolates? What are the prospects for finding relatives for some language isolates, that is, for showing that they belong to larger genetic groupings than those known at present? ${ }^{1}$

To begin, we need to ask, what is a language isolate? In the most common view, an isolate is a language which has no relatives, that is, that has no demonstrable genetic relationship with any other language. It is a language which has not been shown to be the descendent of any ancestral language which has other descendants (daughters). Thus, language isolates are in effect language families with only one member. The best known and most cited language isolates are Basque, Burushaski, and Ainu, though there are many others not so generally known.

Since language isolates are often contrasted with families of related languages, we also need to ask, what is a language family? As is generally known, a language family is a set of languages for which there is sufficient evidence to show that they descend from a single ancestral language and are therefore genetically related. The total number of language families in the world is the set of independent families for which no relationship can be demonstrated with any

\footnotetext{
${ }^{1}$ Portions of this paper are based on Campbell (2011).
} 
other language family. And, as mentioned, a "family" can be composed of but a single language in the case of language isolates.

So, how many independent language families (including isolates) are there in the world? There are approximately 420 (Hammarström 2007, Campbell 2013).

\section{Why Language Isolates and Language Families are not so Very Different}

There are two senses in which language isolates are not very different from language families (of multiple members). First, some language isolates may have had relatives in the past which have disappeared without coming to be known, leaving these languages isolated.

For example, Ket in Siberia is the only surviving language of the Yeniseian family. Nevertheless, there were other Yeneseian languages, now extinct: Arin, Asan, Kott, Pumpokol, and Yugh (Vajda 2001). If these languages had disappeared without a trace, Ket would be considered an isolate. However, since data from these extinct languages was registered before they disappeared, Ket was not left an isolate, rather a member of a family of languages, albeit the only one surviving. Examples such as this show that language isolates could well have once been members of languages families whose other relatives disappeared before they could come to be known, illustrating why in this way language isolates are not so very different from languages families.

\subsection{Did Basque Have Now Extinct Relatives?}

This raises an interesting question: is it possible that Basque once had relatives and is thus not really a language isolate? This brings up a question about the relationship between Basque and Aquitanian. As Trask (1997:411) reports, "probably all Basque scholars now accept that Basque descended more or less directly from Aquitanian" (see also Trask 1995:87, 1997:35). However, is it possible that Aquitanian and Basque are related languages, two members of a language family, rather than Aquitanian being a direct ancestor of Basque?

It is possible that the claim of Basque as a direct descendant of Aquitanian is incorrect. The attestations of Aquitanian are from c. 2000 years ago (see below); however, most languages known from 2,000 years ago have diversified and become families of languages: Romance, Finnic, Slavic, Germanic, Turkic, Mongolian, Polynesian, etc. It is likely that Aquitanian of so long ago would also have diversified into different languages, distinct from one another. However, if no other except Basque survived, Aquitanian could be the direct ancestor of Basque. Another possibility is that Aquitanian had a sister or sisters of its own, diversified from an earlier common ancestor and that Basque descends from a sister of Aquitanian rather than directly from Aquitanian itself. The attestations of Aquitanian allow for this second possibility. 
Although these attestations are sufficiently detailed to confirm that modern Basque and Aquitanian are related, they also show sufficient differences from Basque to suggest the possibility not of a direct ancestor, but as a relative, that possibly Aquitanian and Basque are sister languages representing two branches of the original proto-language. The corpus of Aquitanian data is limited to about 400 personal names and 70 names of deities, found in texts written in Latin. There are no Aquitanian texts larger than these names. (See Michelena 1988, Gorrochategui 1984, 1995, Trask 1997:398-403.) Compare in Table 1 the Aquitanian words (from c.100 CE) with those of Basque on the one hand, and the Gothic words (from $382 \mathrm{CE}$ ) with those of English on the other.

Table 1: Comparison of the relation between Aquitanian and Basque with that between Gothic and English

\begin{tabular}{|c|c|c|c|}
\hline Aquitanian & Basque & Gothic & English \\
\hline arixo & haritz & (faírguni) $^{2}$ & oak \\
\hline atta & aita & fadar & father \\
\hline belex & beltz & swarts & black \\
\hline bon- & on & goPs & good \\
\hline sembe- & seme & sunus & son \\
\hline hanna & anaia & bropar & brother \\
\hline seni- & sehi/seiñ & magus & boy \\
\hline oxson & otso & wulfs & wolf \\
\hline siri(co) & suri & hweits & white \\
\hline ausci & euska(ra) & & 'Basque' \\
\hline
\end{tabular}

It is easy to see that in spite of clear similarities between Aquitanian and Basque, there are also marked differences. It is also clear that the similarities and differences between the cognates from Gothic and English are quite similar to those between Aquitanian and Basque. However, Gothic cannot be considered a direct ancestor of English - the two belong to distinct branches of Germanic. Their differences and similarities, when compared with those between Aquitanian and Basque, turn out to be very similar in nature. Given this similarity, it should be asked, could the relationship between Basque and Aquitanian be that of related languages as exists between Gothic and English, and not like that between Latin and Spanish, where an ancestral language and its descendant are involved?

\subsection{Could Basque Have Modern Relatives?}

In the other sense in which language isolates and language families are not so different from one another, some languages which were thought to be isolates

2 Gothic has no attested form for 'oak'; fairguni 'mountain' is generally believed to have in it the root for 'oak', from Proto-Indo-European *perkw-. 
have in reality proven to be members of small families of related languages. For example, Japanese would be a language isolate if Ryukyuan languages (of Okinawa) had not been shown to be distinct languages, related to Japanese. Thus Japanese belongs to a family of languages (often called Japonic) and is no longer an isolate. Similarly, Etruscan, long cconsidered an isolate, was shown to be related to Lemnian. Lemnian is known from a stella and ceramic fragments from the Greek island of Lemnos, dating from c.400 BCE (cf. Steinbauer 1999:35766).

Some other cases of small families no longer considered language isolates because related languages have come to be known are:

Atakapan Texas and Louisiana (two languages: Atakapa, Akokisa)

Jicaquean (Tol) Honduras (two languages: Tol, Jicaque of El Palmar)

Lencan El Salvador, Honduras (two languages: Chilanga, Honduran Lenca)

Xinkan Guatemala (four languages: Chiquimulilla, Guazacapán, Jumaytepeque, Yupiltepeque)

Hurrian (Hurro-Urartean) Northeast Anatolia, from the state of Mitanni, known from the second and first millennium BCE.

Cases such as these lead us to ask, is it possible that Basque constitutes a small family of languages? Basque would not be considered an isolate if Aquitanian proves to be a separate language, not an ancestor of Basque but genetically related to it. This is quite possibly the case. Also, when two or more 'dialects' are not mutually intelligible, by standard criteria they are considered separate languages. Basque would become a small family if its dialects have diversified so much that some are no longer mutually intelligible. This appears to be the case. Since Proto-Basque (c.600 CE, Lakarra 1995:193) enough time has transpired for Basque to have diversified. As Trask (1997:5) affirms, "the differentiation [between the dialects] is sufficiently distant that speakers of different areas can have significant difficulty understanding one another when using the vernacular form of Basque."

The classification of Basque dialects varies, with disagreements about how many dialects there are and how to classify them; but the following are recognized:

$\begin{array}{ll}\text { Bizkaiera (Vizcaíno, Viscayan) } & \text { Gipuzkera (Guipuzcoano) } \\ \text { Nafarrera garaia (High Navarro) } & \text { Aezkera (Aezcoan) } \\ \text { Salazarera (Salacenco) } & \text { Erronkariera (Roncalese) } \\ \text { Lapurtera (Laburdino, Labourdin) } & \text { Nafarrera behera (Low Navarro) } \\ \text { Zuberoa (Suletino, Souletin). } & \end{array}$

It is generally conceded that at least Zuberoa (Suletino, Souletin) is not mutually intelligible with the others. Given this, some consider Basque no longer 
an isolate, but a small language family. The 2005 edition of Ethnologue (Ethnologue.com) listed three Basque languages, though the 2014 edition has one, noting "some inherent intelligibility among regional varieties except Souletin."

The point is not to insist that Basque formerly had relatives (questioning the status of Aquitanian) nor that it has relatives now (assuming lack of mutual intelligibility), but rather to show that Basque easily could cease to be a language isolate, and therefore that language families and isolates are not so very different.

\section{Further Clarification of the Concept 'Language Isolate'}

It is necessary to distinguish language isolates from unclassified languages, languages so poorly known that they cannot be classified, though sometimes listed as isolates. An unclassified language is one for which there is not enough data (documentation/attestation) to know whether it has relatives - these languages lack sufficient data for them to be compared meaningfully with other languages and therefore their possible kinship remains unknown. Isolated languages are not grouped in larger genetic classifications because for them there do exist data and comparisons of these data with other languages do not reveal linguistic kinship.

There are two sorts of unclassified languages. The first are extinct languages which are too poorly attested to be grouped with any other language or language group. Some examples include:

Adai, Louisiana

Aranama-Tamique, Texas

Camunico, Northeast Italy (survived to 2nd half of 1st millennium BCE)

Eteocretan, Crete, 4-3 centuries BCE.

Ibrerian, Iberian Penninsula (2nd half of 1st millennium BCE to 1st half of 1st millennium CE).

Indus Valley, India and Pakistan, 2500-1900 BCE. (Based on undeciphered inscriptions, whose status as a real writing system is disputed, cf. Farmer et al. 2004).

Kara, possible language of Korea, only from 13 toponyms.

Kaskean, Northeast Anatolia 2nd millennium BCE.

Koguryo possible language, NE China, Manchuria, Korea, 1-8 centuries CE, known only from toponyms and a few words.

Ligurian, Northeast Italy, few words, 300 BCE-100 CE.

Maratino, Northeast Mexico

Minoan Linear A, undeciphered, 1800-1450 BCE.

Mysian, Western Anatolia before the 1st century BCE.

Naolan, Tamaulipas, Mexico.

Northern Picene, Adriatic coast of Italy, 1st millennium BCE.

Pictish, Scotland 7-10 centuries CE, few inscriptions.

Puyo, Manchuria (with Koguryo?), few attested words. 
Quinigua, Northeast Mexico.

Raetic, Northern Italy, Switzerland, Austria, 1st millennium BCE.

Sicanian, Central Sicily, pre-Roman epoch.

Solano, Texas, Northeast Mexico.

Sorothaptic, Iberian Peninsula, pre-Celtic, Bronze Age.

Tartessian, Spain, 1st millennium BCE.

The second kind are the extant languages not classified for lack of data, languages not described sufficiently to compare them with other languages in order to determine whether they may be related. Examples include:

In Africa: Bung, Lufu, Kujargé, perhaps Mpre, Oropom, Rer Bare, Weyto. In Asia and the Pacific: Sentinelese (Andaman Islands), Bhatola (India), Waxianghua (China), Doso (Papua New Guinea), Kehu (Indonesia Papua), Kembra (Indonesia Papua), Lepki (Indonesia Papua).

In South America: Amikoana, Arara, Cagua, Carabayo, Chipiajes, Coxima, Ewarhuyana, Himarimã, Iapama, Kaimbé, Kamba, Kambiwá, Kapinawá, Karahawyana, Kohoroxitari, Korubo, Miarrã, Natagaimas, Pankararé, Papavô, Pataxó-Hãhaãi, Tapeba, Tingui-Boto, Truká, Tremembé, Uru-Pa-In, Wakoná, Wasu, Yarí, etc.

It should be noted that some of these unclassified languages could also be language isolates, but without evidence we cannot know.

\section{How Many Language Isolates are There, Really?}

With the clarification that the unclassified languages are not language isolates, we return to the question, how many isolates are there in the world. The list, compiled from consensus reports from specialists in each region, is:

\section{Africa: [10]}

Bangi-me

Hadza

Kwadi

Mekejir (Shabo)

Ongota (Birale)

Asia: [9]

Ainu

Korean

Hattian Extinct, poorly know

Kusunda

Sumerian Extinct

Australia [7]

Enindhilyagwa (Andilyaugwa)
Centúúm

Jalaa

Laal

Meroitic Extinct

Sandawe

Burushaski

Elamite Extinct

Nihali

Nivkh (Gilyak) (two languages?)

Kakadju (Gaagudu) 
Laragiya Extinct?

Ngurmbur Extinct?

Umbugarla

Oceania [14]

Abinomn, Indonesia Papua)

Anem, New Britain

Elseng, Indonesia Papua

Isirawa, New Guinea

Kuot (Panaras), New Ireland

Mpur, Indonesia Papua

Pele-Ata (Wasi), New Britain

Sulka, New Britain

Yalë (Nagatman), New Guinea

Yele, Papua New Guinea
Minkin Extinct

Tiwi

Abun, Indonesia Papua

Busa (Odiai), New Guinea

Hatam, Indonesia Papua

Kol, New Britain

Massep, Indonesia Papua

Odiai, Papua New Guinea

Pyu, New Guinea

Taiap (Gapun), Papua New Guinea

Yawa, New Guinea (two languages?)

Yuri (Karkar), New Guinea

\section{Europa: [1+]}

Basque (Some would include Tartessian and Iberian, extinct languages of Spain, probably better considered unclassified due to insufficient information.)

North America: [20]

Adai, extinct, Texas, Louisiana

Chimariko, extinct, California

Esselen, extinct, California

Karankawa, extinct, Texas

Kootenai, Idaho, Montana, BC

Salinan, extinct, California

Takelma, extinct

Tonkawa, extinct, Texas

Washo, California, Nevada

Yana, extinct, California

(See Golla et al. 2008.)

\section{Mexico [6]}

Coahuilteco, ext., Texas, NE México

Cuitlatec Extinct, Guerrero

Purhépecha (Tarascan)

(See Campbell 1997)

\section{South America [55]:}

Aikaná, Brazil

Awaké, Venezuela, Brazil

Betoi, Colombia

Candoshi, Peru

Cayuvava, extinct, Bolivia

Chono, Chile

Culle, extinct, Peru

Guató, Brazil
Cayuse, extinct, Oregon

Chitimacha, extinct, Louisiana

Haida, Alaska, British Columbia

Karok, California

Natchez, ext., Mississippi, Louisiana

Siuslaw, extinct, Oregon

Timucua, extinct, Florida

Tunica, ext., Mississippi, Louisiana

Yuchi, Georgia, Oklahoma

Zuni, New Mexico

Cotoname, extinct, NE México

Huave, Oaxaca

Seri, Sonora

Andoque (Andoke), Brazil, Peru

Baenan, Brazil

Camsá (Sibundoy), Colombia

Canichana, Bolivia

Chiquitano, Bolivia

Cofán (A’ingaé), Colombia, Ecuador

Gamela, extinct, Brazil

Irantxe (Iranche, Münkü), Brazil 


\section{Lyle Campbell}

Itonama, Bolivia

Jotí (Yuwana), Venezuela

Kapixaná (Kanoé), Brazil

Koayá (Kwaza, Koaiá), Brazil

Máko (Máku), Brazil

Matanauí, Brazil

Movima, Bolivia

Natú, extinct, Brazil

Omurano, Peru

Pankararú, extinct, Brazil

Rikbaktsá, Brazil

Tarairiú, Brazil

Taushiro (Pinche), Peru

Ticuna, Colombia, Brazil, Peru

Tuxá, extinct, Brazil

Wamoe, Brazil

Xokó, Brazil extinct

Yagan, Chile

Yuracaré, Bolivia

Yurumangui, extinct, Colombia
Jeikó, Brazil

Kaliana (Sapé),Venezuela

Kirirí, Brazil

Kukurá (Cucura, Kokura), ext., Brazil

Mapudungu, Chile

Mochica (Yunga, Chimu), Peru

Munichi (Otanabe), extinct, Peru

Ofayé (Opayé), Brazil

Otí, extinct, Brazil

Puquina, extinct, Bolivia

Sabela (Auca), Ecuador

Taruma, Brazil, Guyana

Tequiraca (Auishiri), Peru

Trumai, Brazil

Urarina, Peru

Warao, Guyana, Surinam, Venezuela

Xukurú, extinct, Brazil

Yaté (Fulniô), Brazil

Yuri (Jurí), extinct, Colombia, Brazil

(See Campbell 2012)

Thus, the total number of isolates in the world is 136. There are c.420 independent language families (including isolates), for which it is not possible to demonstrate a genetic relationship with any other language family. Isolates make up $32 \%$ of all "language families," about one-third of the world's linguistic diversity. Seen from this perspective, isolates are not at all weird; they have as their "cohorts" over one-third of the "language families" of the world.

How do we explain the general attitude that language isolates are weird, so unusual that they are suspicious, and the frequent feeling that languages with no relatives should not be tolerated? I suspect these feelings stem from lack of understanding about how many isolates there are and of how little isolates differ from other languages families, as seen above.

\section{How Can We Advance Our Knowledge of the History of Language Isolates?}

How can we learn about the history of a language without relatives? One attitude about Basque has been that if it has no relatives then it has no history. De Saussure (1916:298, see Michelena 1995:101) said that "we cannot derive anything from Basque because, being an isolate, it does not allow any comparison." Meillet (1925:11-2, see Michelena 1995:101) said that "if a language is an isolate, it lacks history...so if we cannot find a way to demonstrate a relationship between Basque and some other language, there will never be any 
hope of finding out anything about its history." These attitudes make us ask, how can we learn about the history of languages without relatives? Must we accept the claim that an isolate is a language without history? What lessons does the study of Basque and other isolates offer us to understand better how to investigate the history of language isolates in general? As we will see, these attitudes are mistaken -isolates indeed have history and there are means of studying their history. The means that can be employed to learn about the history of isolates include:

Internal reconstruction

Toponyms

Historical reports

Evidence from loanwords

Wörter und Sachen
Philological study of attestations

Personal Names, names of deities

Comparative reconstruction based on

dialects

Language contact and areal linguistics

These are taken up in turn.

\subsection{Internal Reconstruction}

Internal reconstruction is the best known and most used tool to investigate the history of isolates. Excellent examples of its deployment are Michelena (1988, 1995), Lakarra (1995, 2006), and Trask (1997). For example, Lakarra (1995) on the reconstruction of the roots of Pre-Proto-Basque is a valuable application of internal reconstruction to obtain significant historical understanding of a language isolate. Here I offer a single example of a single word, to illustrate what can be gained. Basque 'wine' is reconstructed as *ardano. It has regional variants ardo, ardao, arno, and ardu (Lakarra 1995:195), but even with standard Basque ardo in isolation and ardan- in compounds, internal reconstruction takes us close to the *ardano reconstruction - evidence internal to Basque reveals the change of - $n->$ $\varnothing$ (loss of intervocalic $n$ ), see below.

\subsection{Philological Investigation of Attestations}

Michelena (1988) and Gorrochategui (1984, 1993, 1995) have made very valuable studies of the older attestations of Basque. These include older citations of Basque forms, toponyms, personal names, deity names, and historical reports.

\subsection{Comparative Reconstruction}

A less well known but extremely valuable tool is the comparative method applied not to separate related languages, but to regional dialects. Successful and instructive cases include: Basque (Gorrochategui and Lakarra 1996, 2001, Michelena 1988, 1995, Trask 1997); Ainu (Vovin 1993); Huave (Suárez 1975); 
and Tarascan (Friedrich 1971). These studies show that obviously Meillet, de Saussure, and others were mistaken in insisting that nothing can be known of the history of a language isolate if it has no relatives, and that isolated languages do not lend themselves to any comparison. (See above for Basque dialects.)

\subsection{Loanwords}

Another source of evidence on the history of isolates is loanwords. For example, from the semantic content of the more than 300 ancient loanwords from Latin into Basque it is clear that the Romans had much influence in the areas of laws, administration, technology, religion, and refined culture. Moreover, the relative age of many of these loanwords in Basque is known from phonological traits. Many were borrowed before the changes in Romance of the 5 long and short vowels to a system of just 7 vowels, as in Basque gertu 'certain, ready' [cf. Spanish cierto] < CERTU; joko 'game' [cf. Spanish [juego] < JOCU), and before the palatalization of velar consonants before front vowels, as seen in Basque gertu 'certain, ready' < CERTU; gisu 'lime' < GYPSU) [cf. Spanish gis [xis] (formerly [šis] from [žis]), and before the voicing of intervocalic stops, as in Basque bake 'peace' < PACE) [cf. Spanish paz]. (Michelena 1988, 1995, Trask 1997).

Loanwords can indeed provide considerable historical information about isolates, as in Basque. In another case, from Mesoamerica, we know something of the history of Huave (isolate) and its speakers from words borrowed from MixeZoquean (MZ). Some examples are:

Huave pom 'copal (incense)' < PMZ (Proto-Mixe-Zoquean) *poma [necessary in Mesoamerican ritual]

Huave koy 'rabbit' < PMZ *koya [calendric name]

Huave patsi 'lizzard' < PMZ *patsi [calendric name]

Huave pïk 'feather' < PMZ *pïk [important in pre-Columbian trade] $(\ddot{i}=$ barred "i")

Huave kawak 'chicozapote, mamey' < PMZ *ka'wak 'chicozapote fruit' (the ' $=$ glottal stop)

Huave yati 'anona, chirimoya [soursop]' < Zoque yati, ati.

Several of these loans show cultural influence from Mixe-Zoquean on Huave, loans that reflect cultural concepts in ancient Mesoamerica. They support the hypothesis that the ancient Olmecs - the first highly successful agricultural civilization in Mesoamerica - spoke a Mixe-Zoquean language. Mixe-Zoquean influenced many other languages in the area (Campbell and Kaufman 1976).

\subsection{Areal Linguistic Traits}

Another source of information about the history of isolates is areal linguistics. A linguistic area (Sprachbund) is a geographical region in which, due to language 
contact, languages of the area share structural traits, not through inheritance, but due to borrowing/diffusion. Areal linguistic traits reveal historical contacts and help to explain certain changes in the languages involved, including in isolates, as exemplified by the following areal traits in Basque owed to contact with neighboring languages:

(1) $s$ is apico-alveolar in most varieties, but is apico-post-alveolar for most French Basque speakers (Trask 1997:84), due to French influence.

(2) The Basque phoneme written $<j>$ is [ž] in Zuberoa, presumably due to influence from French. It is $[\mathrm{x}]$ or $[\mathrm{X}]$ in Gipuzkoa and East of Biscaya, from influence from Spanish. (Trask 1997.)

(3) Loss of intervocalic (lenis) - $n$ - and - $l$ - is apparently an areal trait, shared also with Portuguese, Galician, and Asturian. (Trask 1997.)

(4) Basque $u$ has become $\ddot{u}$ in Zuberoa, probably due to influence from French.

(5) Basque initial $h$ - is lost in most dialects (not in Zuberoa). This loss is probably due to influence from Spanish and French. (Trask 1997.)

(6) Basque epenthesized a vowel before initial $r$, e.g. errege 'king' (borrowed from Latin rege) and erloju 'clock' (borrowed from Spanish reloj). This feature is shared also with Aragonese and Gascon (Lakarra 1995:198.)

(7) An older trait possibly due to areal influence, older Basque, Aquitanian, and Iberian all basically lack $p$. (Michelana 1995:112, Trask 1995:78, 87.)

These facts also provide information about the history of Basque.

\subsection{Wörter und Sachen}

Wörter und Sachen strategies also provide information on the history of isolates. These are strategies for detecting past language-and-culture relations.

One strategy involves the analyzability of words (their morphological complexity) - words that can be analyzed into transparent parts are believed to be more recent than words which have no internal analysis. It is believed that words which can be analyzed into parts were created more recently than words which have no such internal composition, thought potentially to be older forms (Campbell 2013:434-6). For example, Basque garagardo 'beer' is analyzable morphologically: garagar 'barley' + ardo 'wine'; however, ardo 'wine' has no evident morphological analysis; therefore, it is inferred that the word for 'wine' is probably older than the word for 'beer'. Similarly, Basque gari 'wheat' is inferred to be older than garagar 'barley', since garagar is a reduplicated from of the word for 'wheat' and thus morphologically analyzable. And, the word for 'wheat' too must be older than that for 'beer', since the 'barley' component of 'beer' is morphologically complex, with 'wheat' in it. Basque janarbi 'radish' is analyzable as jan 'eat + arbi 'turnip'; however, arbi 'turnip' has no such internal structure; it is inferred that the 'turnip' word is older than the 'radish' word. 
Another Wörter und Sachen strategy involves the analyzability of toponyms. It is also inferred that place names that can be analyzed into component parts probably came to be known more recently than those which have no such internal analysis. Thus, for example, it is inferred that York is older than New York, since the latter is composed of identifiable pieces, but not the former. In Basque, since the names of several rivers in the French Basque area have no clear etymology (not analyzable into parts), it is inferred that they are old names, for example Atturri (Adour), Bidasoa, Biduze, Errobi. The names of several rivers of Biscaya, on the other hand, are analyzable, for example Ibaizabal from ibai 'river' + zabal 'wide', and Artibai from arte 'between(?') + ibai 'river'. It is inferred that these latter names are not as old in the language as the former.

A third Wörter und Sachen strategy involves words which bear nonproductive (irregular) morphemes; these are assumed to be possibly older than words composed only of productive morphemes. In Basque, for example, the morph $-d i$ is frozen, not productive, and its presence in the animal names ardi 'sheep', zaldi 'horse', idi 'ox', and ahardi 'sow' suggests that these animals have been known for a long time. For example zaldi 'horse', with non-productive $-d i$, appears older than zamari 'horse', which is confirmed as a loanword (from Latin SAGMARIU 'pack-horse'). In general, though, it is possible only to conclude that words containing the non-productive morphology are old, but nothing can be inferred about the age of words lacking such forms. For example, for otso 'wolf' and ahuntz 'goat', lacking the irregular morphology, it is not possible to say anything of their relative age in the language.

In sum, based on these resources just seen, much is known of the history of Basque. This demonstrates that we can learn about the history of isolates.

\section{What Can We Predict About the Possible Distant Genetic Relationships for Some of These Language Isolates?}

What prospects are there for coming to reliable classifications that would include some of the language isolates in larger genetic groupings than those currently known? In answer to this question, we can cite relatively recent successful demonstrations where it has been possible to show a relationship for some languages previously considered isolates, for example:

Harakbmut-Katukinan? (Adelaar 2000)

Lule-Vilela (Lule and Vilela) (Viegas Barros 2001)

Western Torres Island and Pama-Nyungan (Alpher, O'grady, and Bowern forthcoming)

Tikuna-Yurí (Tikuna and Yurí) (see Campbell 2012)

Judging from these successful instances, it can be expected that with more data and dedication, following adequate methods (see Campbell and Poser 2008), more cases of genetic relationship involving some language isolates will be discovered. 
Nevertheless, it is not to be expected that there will be many of these. In particular in the case of Basque it has already been shown that the proposals that have been made do not support the assumption of a genetic relationship between Basque and any other language or language family (Lakarra 1996, 2006, Trask 1995).

\section{$7 \quad$ Conclusions}

From the above considerations, the conclusions that follow are:

(1) There is nothing unusual about isolates; there are 136 isolates in the world.

(2) Language isolates make up about one third of the language families in the world's total of c.420 independent families (including isolates).

(3) Language isolates are not very different from languages which have relatives. Isolates could easily have had relatives now lost or could diversify into small families of related languages.

(4) Language isolates, which have data, should not be confused with unclassified languages, which are not classified for lack of data.

(5) We have made progress in the search for relatives of Basque and other language isolates in that we have proven that many hypotheses of distant genetic relationship are not supported by the evidence, and much more is known now of the methods necessary to demonstrate a genetic relationship among languages (see Campbell and Poser 2008).

(6) In spite of doubts about discovering anything about the history of isolates, there are several resources (tools, techniques) which can help to recover considerable historical information about these languages; these include: internal reconstruction, philological investigation of earlier attestations, comparative reconstruction based on the dialects, evidence from loanwords, language contact and areal linguistics, and Wörter und Sachen strategies.

(7) It can be expected that with more data and dedication, employing adequate methods, new genetic relationships will be discovered for some language isolates. However, it is not to be expected that there will be many such cases, and this is highly unlikely in the case of Basque.

\section{References}

Adelaar, Willem F. H. 2000. Propuesta de un Nuevo Vínculo Genético entre dos Grupos Lingüísticos Indígenas de la Amazonia Occidental: Harakmbut y Katukina. Actas I Congreso de Lenguas Indígenas de Sudamérica, ed. by Luis Miranda Esquirre, 2:219-236. Lima: Editorial Universitaria.

Alpher, Barry, Geoffrey O'grady, and Claire Bowern. Forthcoming. Western Torres Strait Language Classification and Development. 
Bowern, Claire. 2007. Australian Models of Language Spread. Paper presented at the International Conference on Historical Linguistics, Aug 6-12, 2007, University of Quebec, Montreal.

Campbell , Lyle. 1997. American Indian Languages: The Historical Linguistics of Native America. Oxford: Oxford University Press.

. 2011. La investigación histórica de las lenguas aisladas, o ¿es raro el vasco? II. Congreso de la Cátedra Luis Michelana, ed. by Joseba A. Lakarra, Joaquín Gorrochategui, and Blanca Urgell, 23-40. Vitoria Gasteiz: Editorial de la Universidad del País Vasco.

. 2012. The classification of South American indigenous languages. The Indigenous Languages of South America: A Comprehensive Guide, ed. by Lyle Campbell and Verónica Grondona, 59-166. (The World of Linguistics, vol. 2.) Berlin: Mouton de Gruyter.

. 2013. Historical Linguistics: An Introduction. ( $3^{\text {rd }}$ edition). Edinburgh: Edinburgh University Press, and Cambridge, MA: MIT Press.

Campbell, Lyle and Terrence Kaufman. 1976. A Linguistic Look at the Olmecs. American Antiquity 41:80-89.

Campbell, Lyle \& William J. Poser. 2008. Language Classification: History and Method. Cambridge: Cambridge University Press.

Farmer, Steve, Richard Sproat, and Michael Witzel. 2004. The Collapse of the Indus-Script Thesis: The Myth of a Literate Harappan Civilization. Electronic Journal of Vedic Studies 11:19-57.

Friedrich, Paul. 1971. Dialectal Variation in Tarascan Phonology. International Journal of American Linguistics 37:164-187.

Golla, Victor, Ives Goddard, Lyle Campbell, Marianne Mithun, and Mauricio Mixco. 2008. North America. Atlas of the World's Languages, ed. by Chris Moseley and Ron Asher, 7-41. London: Routledge.

Gorrochategui, Joaquín. 1984. Onomástica indígena de Aquitania. Bilbao: Universidad del País Vasco.

- 1993. Onomástica Indígena de Aquitania: Adiciones y Correcciones I. Sprachen und Schriften des antiken Mittelmeerraums: Festschrift für Jürgen Untermann, ed. by Frank Heidermanns, Helmut Rix, and Elmar Seebold, 145155. Innsbruck: Innsbrucker Beiträge zur Sprachwissenschaft. 
. 1995. The Basque Language and its Neighbors in Antiquity. Towards a History of the Basque Language, ed. by José Ignacio Hualde, Joseba A. Lakarra, and R.L. Trask, 31-63. Amsterdam: Benjamins.

Gorrochategui, Joaquín and Joseba Lakkara. 1996. Nuevas aportaciones a la reconstruccíon del protovasco. La Hispania prerromana: Actas del VI Coloquio sobre lenguas y culturas de la Penísula Ibérica, ed. Por F. Villar y J. d'Encarnação, 101-145. Salamanca.

- 2001. Comparación Lingüística, Filología y Reconstrucción del Protovasco. Religión, Lengua y Cultura Prerromanas de Hispania: Actas del VIII Coloquio sobre Lenguas y Culturas de la Penísula Ibérica, ed. Por F. Villar y J. d'Encarnação, 407-438. Salamanca.

Hammarström, Harald. 2007. The Languages Families of the World: A Critical Synopsis. www.cs.chalmers.se/ harald2/.

Lakarra, Joseba A. 1995. Reconstructing the Pre-Proto-Basque Root. Towards a History of the Basque Language, ed. by José Ignacio Hualde, Joseba A. Lakarra, and R.L. Trask, 189-206. Amsterdam: Benjamins.

- 1996. Sobre el Europeo Antiguo y la Reconstrucción del Protovasco. Anuario del Seminario de Filología Vasca “Julio de Urquijo” 30:1-70.

- 2006. Protovasco, Munda y Otros: Reconstrucción Interna y Tipología Holística Diacrónica. Oihenart: Cuadernos de Lengua y Literatura 21:229-322.

Meillet, André. 1925. La Méthode Comparative en Linguistique Historique. Olso: H. Aschehoug \& Co.

Michelena [Mitxelena], Luis [Koldo]. 1988. Sobre Historia de la Lengua Vasca, ed. by Joseba A. Lakarra. (Suplementos del Anuario de Filología Vasca 'Julio de Urquijo', 10.) Donastia/San Sebastian: Diputación Foral de Guipúzcoa.

. 1995. The Ancient Basque Consonants. Towards a History of the Basque Language, ed. by José Ignacio Hualde, Joseba A. Lakarra, and R.L. Trask, 101135. Amsterdam: Benjamins.

Saussure, Ferdinand de. 1916. Cours de Linguistique Générale. Paris: Payot.

Steinbauer, Dieter H. 1999. Neues Handbuch des Etruskischen. St. Katharinen: Scripta Mercaturae. 
Suárez, Jorge. 1975. Estudios Huaves. (Colección Científica, Lingüística, 22.) México: Departamento de Lingüística, INAH.

Tovar, Antonio. 1957. The Basque language. Philadelphia: University of Pennsylvania Press.

Trask, L. R. 1995. Origin and Relatives of the Basque Language: Review of the Evidence. Towards a History of the Basque Language, ed. by José Ignacio Hualde, Joseba A. Lakarra, and R.L. Trask, 65-99. Amsterdam: Benjamins.

_. 1997. History of Basque. London: Routledge.

Vajda, Edward. 2001. Yeniseian peoples and languages: a history of Yeniseian studies. London: Curzon.

Viegas Barros, J. Pedro. 2001. Evidencias del Parentesco de las Lenguas Lule y Vilela. (Colección Folklore y Antropología 4.) Santa Fe: Subsecretaría de la Provincia de Santa Fe.

Vovin, Alexander. 1993. A Reconstruction of Proto-Ainu. Leiden: Brill.

Lyle Campbell

University of Hawai'i at Mānoa

Department of Linguistics

Moore Hall 569, 1890 East-West Road

Honolulu, HI 96822

lylecamp@hawaii.edu 